\title{
Antibacterial and Cytotoxic Activities of Sponges Collected off the Coast of Togean Islands, Indonesia
}

\author{
Muhammad Sulaiman Zubair ${ }^{*}$, Subehan Lallo², Masteria Yunovilsa Putra ${ }^{3}$, Tri Aryono Hadi ${ }^{3}$, Ibrahim Jantan ${ }^{4}$
}

\section{Muhammad Sulaiman Zubair $^{1 *}$, Subehan Lallo², Masteria Yunovilsa Putra ${ }^{3}$, Tri Aryono Hadi ${ }^{3}$, Ibrahim Jantan ${ }^{4}$}

\author{
'Department of Pharmacy, Faculty of \\ Sciences, Tadulako University, Kampus \\ Bumi Tadulako, Palu, INDONESIA. \\ ${ }^{2}$ Department of Pharmacy, Faculty \\ of Pharmacy, Hasanuddin University, \\ Makassar, INDONESIA. \\ ${ }^{3}$ Research Centre for Oceanography, \\ Indonesian Institute of Sciences, \\ J. Pasir Putih I, Ancol Timur, Jakarta, \\ INDONESIA. \\ ${ }^{4}$ Drug and Herbal Research Center, \\ Faculty of Pharmacy, National \\ University of Malaysia, Kuala Lumpur, \\ MALAYSIA.
}

\section{Correspondence}

Muhammad Sulaiman Zubair

Program Studi Farmasi FMIPA, Universitas Tadulako, Jalan Soekarno Hatta, Tondo Palu, Central Sulawesi, 94119,

INDONESIA.

Phone no : +62 85242083654

E-mail: sulaiman_zubair80@yahoo.co.id

History

- Submission Date: 26-02-2018;

- Review completed: 15-03-2018;

- Accepted Date: 11-05-2018

\section{DOI : 10.5530/pj.2018.5.168}

Article Available online

http://www.phcogj.com/v10/i5

\section{Copyright}

(c) 2018 Phcog.Net. This is an openaccess article distributed under the terms of the Creative Commons Attribution 4.0

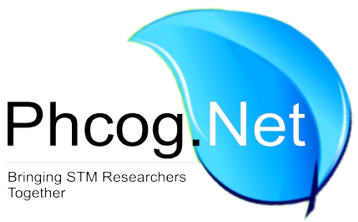

\begin{abstract}
Context: Marine sponges (Porifera: Demospongia) have astonishing structural diversity and broad biological activities. Aims: To evaluate the antibacterial and cytotoxic activities of five sponges collected off the coast of Togean Islands, Indonesia, identified as Spheciospongia inconstan, Melophlus sarasironum, Oceanapia amboinensis, Biemna sp and Axinella sp. Methods and Material: All dried sponges materials were extracted by maceration method using methanol and then evaporated by the rotary evaporator to obtain viscous extracts. The determination of antibacterial activity was performed by well agar diffusion method against Staphylococcus aureus and Escherichia coli while the cytotoxic activity was determined by MTT methods on human breast adenocarcinoma (MCF-7) and human colon colorectal carcinoma (HCT-116), followed by determination of the apoptosis mechanism by Annexin V-FTIC assay. Results: $M$. sarasinorum and Axinella sp showed strong inhibition against S.aureus and E.coli with the diameter of inhibition of $14.21 \pm 0.92 \mathrm{~mm}$ and $14.36 \pm 0.92 \mathrm{~mm}$, and $10.01 \pm 2.65$ $\mathrm{mm}$ and $12.07 \pm 1.54 \mathrm{~mm}$, respectively. Moreover, they also exhibited potent cytotoxicity on HCT-116 with $\mathrm{IC}_{50}$ values of 0.002 and $8.518 \mu \mathrm{g} / \mathrm{mL}$, respectively. Meanwhile, on MCF-7, only M. sarasinorum showed moderate inhibition with an $I C_{50}$ value of $87.35 \mu \mathrm{g} / \mathrm{mL}$. Annexin V-FTIC assay clearly showed that the cytotoxic mechanism of $M$. sarasinorum and Axinella $s p$ on HCT-116 and MCF-7 was via apoptosis induction. Conclusion: The sponges of M. Sarasinorum and Axinella sp are undergoing further analysis to identify the active constituents which could be developed as potential antibacterial and anticancer agents.

Key words: Sponges, Togean Islands, Cytotoxicity, Antibacterial, MTT.

Key Messages: Screening of antibacterial and cytotoxic activities of sponges, collected off Togean Islands, Indonesia, using well agar diffusion and MTT methods, followed by determination of the apoptosis mechanism by Annexin V-FTIC assay have found the high potency of Melophlus sarasinorum and Axinella sp to be antibacterial and anticancer drugs.
\end{abstract}

\section{INTRODUCTION}

The increasing case of infection diseases caused by bacteria, as well as the growth of antibiotics and anticancer drugs resistance in the worldwide have encourage scientist to search the new source of antibiotic and anticancer drugs, particularly from marine bioactive compounds. ${ }^{1}$ The exploration of marine environment have progressively improved in the past 50 year that possessing around thousands of unique chemical structure of new bioactive compounds from marine. Among marine organisms, marine sponges (porifera: Demospongiae) have been considered as a largest source of unusual metabolites and bioactive compounds that attributes to various biomedical pharmaceutical importance such as antibacterial, anticancer, antifungal, antiprotozoal and antiviral activities.-5 Some of them are halichondrin B from Halichondria okadai which is under preclinical anticancer agent, aurantosides from Siliquariaspongia japonica and Homophynia conferta and spongistatin 1 from Hyrtio serecta which are commercially available. ${ }^{6}$

Indonesian coast is one of the richest biodiversity for marine organisms in the world. Literature studies and informal database record-based review confirmed the richness of sponges along the Indonesian's shoreline. However, the published knowledge based of Indonesian sponge's organisms is sorely incomplete. Much of the sponge's materials are still needing to be described for species identification and many sponge's locations still need to be explored.

Previously, our study on soft corals of Sarcophyton trocheliophorum have found numerous novel metabolites possessing antibacterial and antitumor activities. ${ }^{8}$ In continuing our focus research on marine organism to identify compounds with medicinal prospect, particularly from Indonesian sea, our study now starting on some sponges collected off Togean Islands, Indonesia. Here, we report the screening assay for antibacterial and cytotoxic activities of sponges methanolic extracts on two pathogenic bacteria Staphylococcus aureus and Escherichia coli, 
two human carcinoma cells MCF-7 and HCT-116 and two human normal cells CCD and NHDF followed by apoptosis assay for the most cytotoxic extracts.

\section{MATERIALS AND METHODS}

\section{Study area}

Togean islands is in the north, eastward-projecting peninsula of central Sulawesi (Figure 1 and 2). It occupies the central portion of Tomini Bay, stretching over about $90 \mathrm{~km}$. The land area of the Togean Group covers about $755 \mathrm{~km}^{2}$ and contains 66 islands of which Batudaka, Talatakoh, Waleakodi, Waleabahi, Una-una and Togean are the largest. ${ }^{9}$

\section{Materials}

All samples of sponges were collected in January 2017 on Togean Islands, Tojo Una-una, Indonesia at a depth of 5-10 m and identified by Tri Aryono Hadi (co-author) at Research Center for Oceanography- Indonesian Institute of Science, Jakarta. A voucher sample was deposited at Laboratory of Phytochemistry, Department of Pharmacy, Tadulako University.

\section{Extraction}

Material of sponges were minced and repeatedly extracted for 3-5 x $24 \mathrm{~h}$ by maceration method with $\mathrm{Me}-\mathrm{OH}$ as a solvent at room temperature. Then each obtained extract was evaporated by using rotary evaporator to reach a viscous extract. Each of extracts was subjected to antibacterial and cytotoxic activity tests.

\section{Antibacterial Screening}

Antibacterial screening was performed against two types of bacteria: Staphylococcus aureus and Escherichia coli by using agar well diffusion method. ${ }^{10}$ Briefly, $0.1 \mathrm{~mL}$ of suspended bacterium in sterile medium $\left(1.5 \times 10^{8} \mathrm{CFU} / \mathrm{mL}\right)$ was spread on nutrien agar media. Then $50 \mu \mathrm{L}$ of each sample $(1000,500$ and $250 \mathrm{mg} / \mathrm{mL})$ was poured into the wells (6-mm diameter). All plates were left for $1 \mathrm{~h}$ at $48^{\circ} \mathrm{C}$ and then incubated for $24 \mathrm{~h}$ at $37^{\circ} \mathrm{C}$ for bacteria. Inhibition zone diameters formed around the well were measured and the mean diameter of three replicates was calculated. DMSO was used as a negative control and chloramphenicol as a positive control.

\section{Cytotoxic activity}

Cytotoxic activity was applied on human breast adenocarcinoma (MCF-7), human colon colorectal carcinoma (HCT-116) and two normal cell lines NHDF and CCD-118 by MTT method as described in our previous study. ${ }^{11}$ Doxorubicin and fluorouracil were used as a positive standard anticancer drug. The stock samples were diluted with RPMI-1640 medium to desired concentrations of $62.5,125,250,500$ and $1000 \mu \mathrm{g} / \mathrm{mL}$. The final concentration of dimethyl sulfoxide (DMSO) in each sample was $1 \% \mathrm{v} / \mathrm{v}$. The cancer cells were batch cultured for $10 \mathrm{~d}$, then seeded in 96 well plates of $1 \times 10^{4}$ cells/well in fresh complete growth medium in 96 -well microliter plastic plates at $37^{\circ} \mathrm{C}$ for $24 \mathrm{~h}$ under $5 \% \mathrm{CO}_{2}$ using a water jacketed carbon dioxide incubator (CelCulture, Esco Medical ApS, Denmark). The medium (without serum) was added and cells were incubated either alone (negative control) or with different concentrations of sample. After $48 \mathrm{~h}$ of incubation, cells were added with $10 \mu \mathrm{l} /$ well of MTT $(5 \mathrm{mg} / \mathrm{mL})$ and incubated for $4 \mathrm{~h}$ in incubator at $37^{\circ} \mathrm{C}$ in $5 \% \mathrm{CO}_{2}$ humidified atmosphere. The reaction was stopped by $100 \mu \mathrm{l}$ dimethylsulfoxide (DMSO). The plate was then incubated for $15 \mathrm{~min}$. The absorbance of each well was read at $550 \mathrm{~nm}$ wavelength in Elisa Reader (Infinite M200 pro Nano Quant, Tecan, Switzerland), using wells without cells as blanks. All experiments were performed in triplicate. The effect of compounds on proliferation of cancer cells was expressed as the $\%$ cytoviability, using the following formula:

$$
\% \text { Cytoviability }=\frac{\text { Absorbance of treated cells }}{\text { Absorbance of control cells }} \times 100 \%
$$

The $\mathrm{IC}_{50}$ calculation was done statistically by probit analysis using SPSS 17.0 (SPSS. Inc, Chicago IL, USA), in which the series of dose-response data and the percentage of cytoviability were plotted together.

\section{Annexin V-FITC Apoptosis Assay}

Annexin V-FITC Apoptosis Assay on cancer cells (MCF-7 and HCT-116) were seeded as described above and then incubated with different treatments for $24 \mathrm{~h}$. Cells were harvested, washed twice with PBS and centrifuged. In brief, $1 \times 10^{5}$ of cells were treated with annexin V-FITC and propidium iodide (PI) using the apoptosis detection kit (BD Biosciences, San Jose, CA) according to the manufacturer's protocol. Annexin V-FITC and PI binding were analysed by flow cytometry on FACScanto II (BD Biosciences, San Jose, CA) without gating restrictions using 10,000 cells. Data were collected using logarithmic amplification of both the FL1 (FITC-A) and the FL2 (PI-A) channels. Quadrant analysis of coordinate dot plots was performed with Cell Quest software. Unstained cells were used to adjust the photomultiplier voltage and for compensation setting adjustment to eliminate spectral overlap between the FL1 and the FL2 signals.

\section{RESULTS}

Antibacterial test was performed by well agar diffusion method. Staphylococcus aureus and Escherichia coli were chosen as tested bacteria as the representative of gram positive and gram-negative bacteria. The inhibition of both bacteria used to be said that the extract has broad spectrum type of inhibition. As it can be seen in Table 1, Only Melophlus sarasinorum and Axinella sp have inhibition on Staphylococcus aureus and Escherichia coli, with diameter of inhibition zone of $14.21 \pm 0.92 \mathrm{~mm}$ and $14.36 \pm 0.92 \mathrm{~mm}$, and $10.01 \pm 2.65 \mathrm{~mm}$ and $12.07 \pm 1.54 \mathrm{~mm}$, respectively. Therefore, it can be suggested that the extract of Melophlus sarasinorum and Axinella sp have a broad spectrum of antibacterial activities. Further cytotoxic activity against human colon carcinoma (HCT-116) of the all extracts of sponges, found that the cytotoxic effects were dose and time dependent. It showed that Melophlus sarasinorum and Axinella sp methanolic extract have time dependent potent cytotoxicity with the $\mathrm{IC}_{50}$ of 0.002 and $8.518 \mu \mathrm{g} / \mathrm{mL}$, respectively after $48 \mathrm{~h}$ incubation (Table 2). Meanwhile, only Melophlus sarasinorum showed cytotoxicity on MCF-7 with the $\mathrm{IC}_{50}$ of $87.35 \mu \mathrm{g} / \mathrm{mL}$ after $48 \mathrm{~h}$ incubation. Axinella sp showed high selectivity on cell growth inhibition where it is found to be not toxic on both CCD and NHDF normal cells.

Table 1: Antibacterial activity of Togean island sponges.

\begin{tabular}{ccc}
\hline Sponges & \multicolumn{1}{c}{$\begin{array}{c}\text { Mean Diameter of Inhibition Zone }(\mathrm{mm}) \text { at } \\
1000 \mathrm{mg} / \mathrm{ml}\end{array}$} \\
\cline { 2 - 3 } & Staphylococcus aureus & Escherichia coli \\
\hline $\begin{array}{c}\text { Spheciospongia } \\
\text { inconstant }\end{array}$ & - & - \\
$\begin{array}{c}\text { Melophlus sarasironum } \\
\text { Oceanapia amboinensis. }\end{array}$ & $14.21 \pm 0.93$ & $14.36 \pm 0.92$ \\
Biemna sp. & - & - \\
Axinella sp. & - & $12.07 \pm 1.54$ \\
Chloramphenicol $^{\text {a }}$ & $10.01 \pm 2.65$ & $45.53 \pm 0.55$ \\
\hline
\end{tabular}

${ }^{\mathrm{a}}=$ Chloramphenicol was tested at $1 \mathrm{mg} / \mathrm{mL}$. 
Table 2: Cytotoxic activity of Togean Islands sponges.

\begin{tabular}{|c|c|c|c|c|c|c|}
\hline \multirow[t]{3}{*}{ Sponges } & \multicolumn{6}{|c|}{ Inhibition Concentration, $\mathrm{IC}_{50}(\mu \mathrm{g} / \mathrm{mL})$} \\
\hline & \multicolumn{2}{|c|}{ MCF-7 } & \multicolumn{2}{|c|}{ HCT-116 } & \multirow{2}{*}{$\frac{C C D}{24 \mathrm{H}}$} & \multirow{2}{*}{$\frac{\text { NHDF }}{24 \mathrm{H}}$} \\
\hline & $24 \mathrm{H}$ & $48 \mathrm{H}$ & $24 \mathrm{H}$ & $48 \mathrm{H}$ & & \\
\hline Spheciospongia inconstant & 281.84 & 129.25 & 229.47 & 229.47 & ND & ND \\
\hline Melophlus sarasironum & 51.46 & 87.35 & 0.75 & 0.002 & 14.20 & 8.47 \\
\hline Oceanapia amboinensis. & 213.34 & 246.15 & 58.68 & 45.33 & 2.01 & 132.42 \\
\hline Biemna sp & 269.43 & 213.32 & 780.40 & 284.13 & ND & ND \\
\hline Axinella $s p$ & 250.75 & 756.90 & 27.03 & 8.52 & NT & NT \\
\hline Doxorubicin & 0.024 & & - & & ND & ND \\
\hline Fluorouracil & - & & 8.915 & & ND & ND \\
\hline
\end{tabular}

$\mathrm{ND}=$ Not determined, $\mathrm{NT}=$ No toxicity.

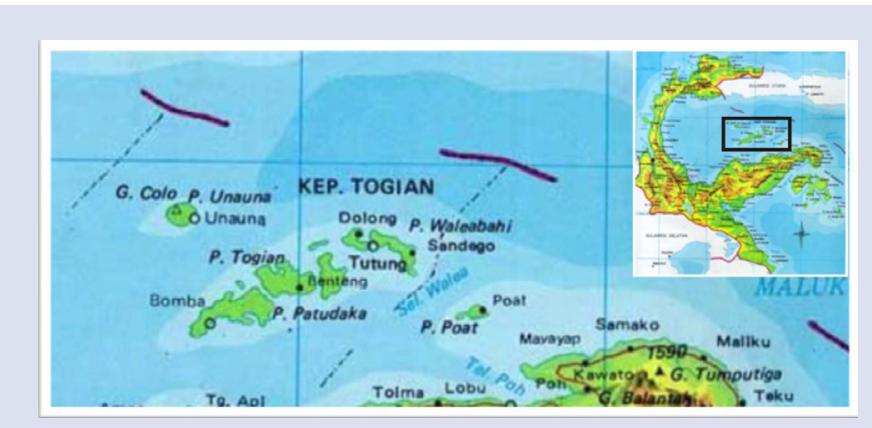

Figure 1: Location of study: Togean Islands, Central Sulawesi, Indonesia.

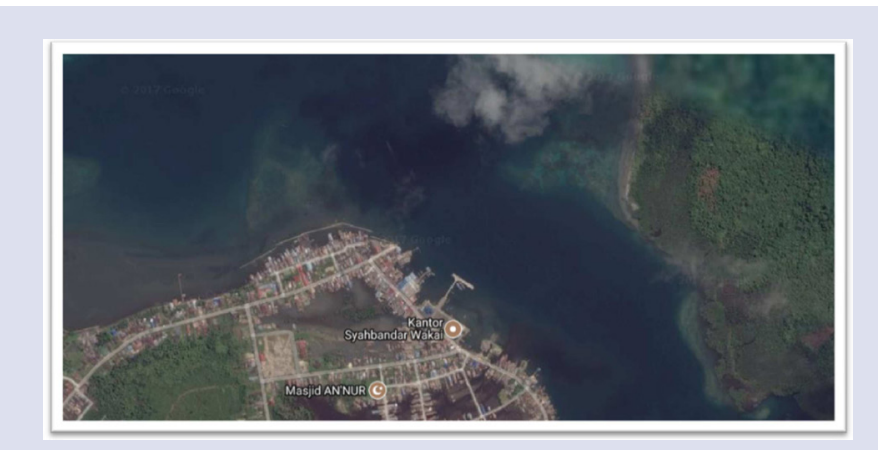

Figure 2: Aerial view of sample collection site.

\section{DISCUSSION}

The aims of this study are to screen for the most potent antibacterial and cytotoxic activity of sponges collected off Togean Islands, identified as Spheciospongia inconstan, Melophlus sarasironum, Oceanapia amboinensis, Biemna sp and Axinella sp. (Figure 3).

Melophlus sarasinorum (family Ancorinidae) has been reported to contain nine triterpene glycosides, namely sarasinosides A1, A2, A3, B1, B2, B3, C1, C2, and C3. ${ }^{12,13}$ Interestingly, these sarasinosides compounds exhibited cytotoxic against several cell lines. Schmitz et al.(1988) reported the cytotoxicity of sarasinoside A1 against human lymphocytic leukemia cell line with the $\mathrm{ED}_{50}$ of $2.8 \mu \mathrm{g} / \mathrm{mL}^{14,15}$ Lee et al. (2000) proved the cytotoxic activities of sarasinosides $\mathrm{A} 2$ and $\mathrm{A} 3$ against human leukemia cell line $\mathrm{K} 562$ with $\mathrm{ED}_{50}$ of 6.5 and $17.1 \mu \mathrm{g} / \mathrm{mL}$, respectively. ${ }^{16}$ Moreover, four new tetramic acid derivates, namely Melophlins P, Q, R and S, have potent cytotoxicity against murine leukemic cell lines with the $\mathrm{IC}_{50}$ of

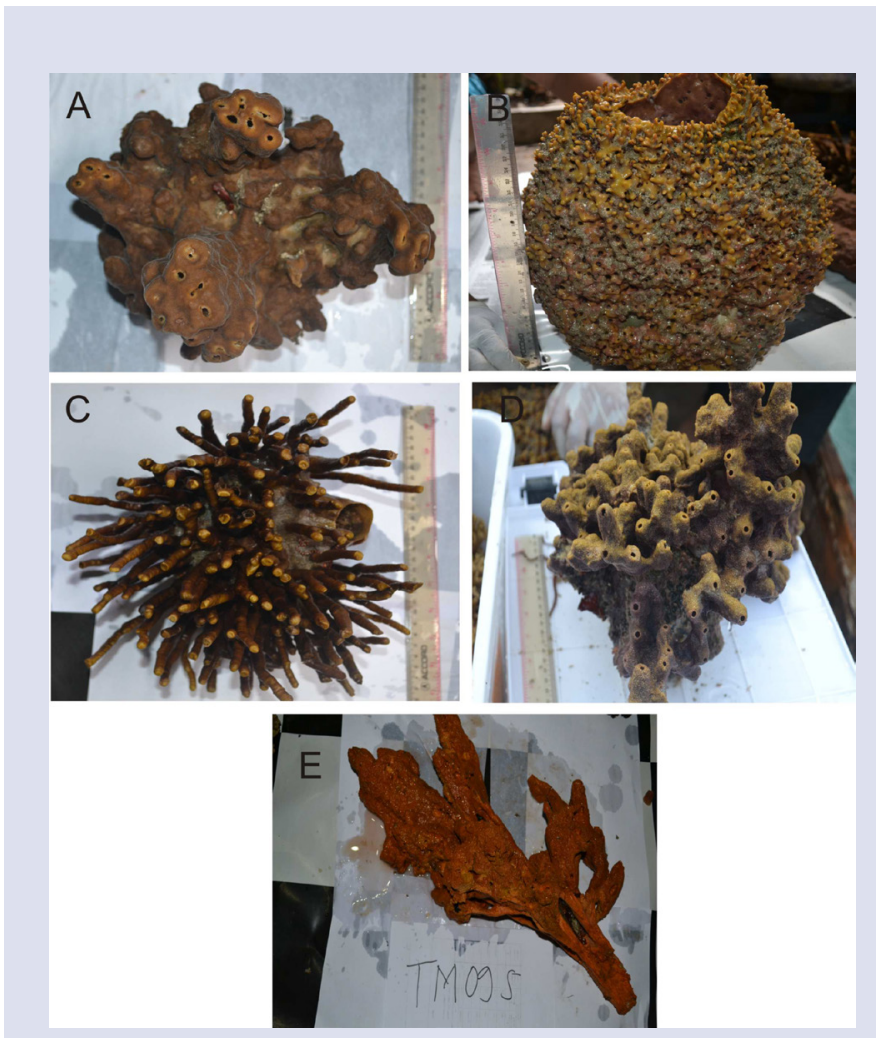

Figure 3: Sponges collected from Togean Islands. A: Spheciospongia inconstan, B: Melophlus sarasironum, C: Oceanapia amboinensis, D: Biemna sp and E: Axinella sp.

20.0, 10.5, 0.85 and $5.13 \mathrm{uM}$, respectively. ${ }^{17}$ Meanwhile, Axinella sp has been reported to contain polyalkilated cyclopentindoles, herbindoles A, $\mathrm{B}$ and $\mathrm{C}$, which are cytotoxic to $\mathrm{KB}$ cells. ${ }^{18}$ These reported data supported our result. However, there is still a lack in the mechanism of cytotoxicity reported. Therefore, we further identify the possible apoptosis mechanism of the potential extracts (Melophlus sarasinorum and Axinella sp) by Annexin V-FITC assay. Apoptosis is the programmed cell death process. It plays an important role in the regulation of tissue development and homeostatis. Therefore, the induction of apoptosis will suppress the tumor progression. ${ }^{19}$ The result showed that methanolic extract of Melophlus sarasinorum and Axinella sp have significant percentage of early and late apoptosis on HCT-116 cell lines with the value of $89.70 \%$ and $34.00 \%$, 


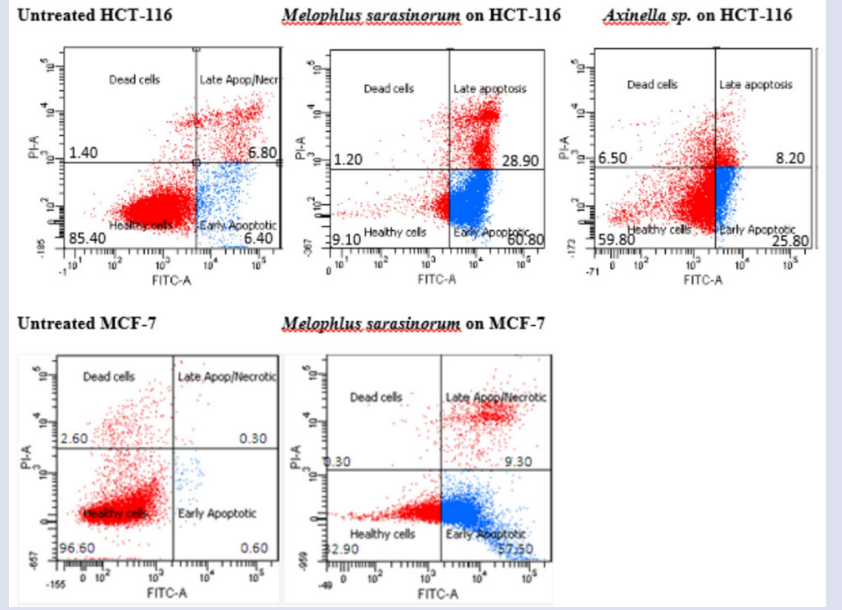

Figure 4: Effect of Melophlus sarasinorum and Axinella sp methanolic extract on HCT-116 and MCF-7 on annexin V-FITC-positive staining. The four quadrants identified as LL (healthy cells); LR (early apoptotic); UR (late apoptotic) and UL (necrotic).

respectively. Meanwhile, on MCF-7, methanolic extract of Melophlus sarasinorum showed significant percentage of early and late apoptosis of $66.80 \%$ (Figure 4 ). Although some studies revealed the potency of bioactive secondary metabolites from these two sponges, the mechanism of anticancer via apoptosis induction obtained in this study suggested for further isolation and purification for their metabolites.

\section{CONCLUSION}

Melophlus sarasinorum and Axinella sp are the most potential extracts from our biological activity screening that have broad spectrum of antibacterial activity. Moreover, it also found to have potent cytotoxicity and apoptosis induction on HCT-116. This study suggested for further isolation and identification of the bioactive compound from these two sponges.

\section{ACKNOWLEDGEMENT}

Authors would like to acknowledge the Ministry of Research, Technology and Higher Education, Republic of Indonesia for financial support via Postdoctoral Research Grant (703.c/UN28.2/PL/2017).

\section{CONFLICT OF INTEREST}

The authors declare no conflict of interest.

\section{ABBREVIATIONS}

MCF-7: Michigan Cancer Foundation-7; HCT-116: Homosapiens Colon Colorectal; CCD: Normal Colon Fibroblast; NHDF: Normal Human
Dermal Fibroblast; MTT: 3-(4, 5-dimerhylthiazol-2-yl)-2,5-diphenyltetrazolium bromide; RPMI 1640 medium: Roswell Park Memorial Institute; SDS: Sodium Dodesilsulfat; DMSO: dimethyl sulfoxide; CFU: Colony-forming Unit; IC $_{50}$ : Inhibition Concentration; SPSS: Statistical Package for the Social Sciences.

\section{REFERENCES}

1. Afifi R, Abdel-Nabi IM, El-Shaikh K. Antibacterial activity from soft corals of the Red Sea, Saudi Arabia. J Taibah Univ Sci. 2016;10(6):887-95.

2. Blunt JW, Copp BR, Munro MH, Northcote PT, Prinsep MR. Marine natural products. Nat Prod Rep. 2015;32(2):170-244.

3. Blunt JW, Copp BR, Hu WP, Munro MH, Northcote PT, Prinsep MR. Marine natural products. Nat Prod Rep. 2008;25(1):31-86.

4. Chen W, LiY, Guo Y. Terpenoids of Sinularia soft corals: chemistry and bioactivity. Acta Pharm Sin B. 2012;2(3):227-37.

5. Putra MY, Wibowo JT, Murniasih T, Rasyid A. Evaluation of antibacterial activity from Indonesian marine soft coral Sinularia sp. AIP Conf Proc. 2016;1744(1):20-39.

6. Monks NR, Lerner C, Henriques AT, Farias FM, Schapoval EES, Suyenaga ES, et al. Anticancer, antichemotactic and antimicrobial activities of marine sponges collected off the coast of Santa Catarina, southern Brazil. J Exp Mar Biol Ecol. 2002;281(1-2): 1-12.

7. DeVoogd NJ, Van Soest RW. Indonesian sponges of the genus Petrosia Vosmaer (Demospongiae: Haplosclerida ). Zool Med Leiden. 2002;76(16):193-209.

8. Zubair M, Alarif W, Al-Footy K, Mohamed PH, Ali M, Basaif S, et al,. New antimicrobial biscembrane hydrocarbon and cembranoid diterpenes from the soft coral Sarcophyton trocheliophorum. Turk J Chem. 2016;40(3):385-92.

9. Allen GR, McKenna SA. A marine rapid assessment of the Togean and Banggai Islands, Sulawesi, Indonesia. RAP Bulletin of Biological Assessment. 2001:20.

10. Limberger RP, Sobral MEG, Zuanazzi JAS, Moreno PRH, Schapoval EES, Henriques AT. Biological activities and essential oil composition of leaves of Blepharoclyxsalicifolius. Pharm Biol. 2001;39(4):308-11.

11. Zubair MS, Anam S, Lallo S. Cytotoxic activity and phytochemical standardization of Lunasiaamara Blanco wood extract. Asian Pac J Tropical Biomed. 2016;6(11):962-6.

12. Kitagawa I, Kobayashi M, Okamoto Y, Yoshikawa M, Hamamoto Y. Structures of sarasinosides $\mathrm{A} 1, \mathrm{~B} 1$, and $\mathrm{C} 1$, new norlanostane-triterpenoid olygoglycosides from the Palauanmarine sponge Asteropussarasinosum. Chem Pharm Bull. 1987;35(12):5036-9

13. Kobayashi $M$, Okamoto $Y$, Kitagawa I. Marine natural products. XXVIII. The structures of sarasinosides $A 1, A 2, A 3, B 1, B 2, B 3, C 1, C 2$, and C3, nine new norlanostane-triterpenoidal olygoglycosides from the Palauan marine sponge Asteropus sarasinosum. Chem Pharm Bull.1991;39(11):2867-77.

14. Schmitz FJ, Ksebati MB, Gunasekera SP, Agarwal S. Sarasinoside A1: A saponincontaining amino sugars isolated from a sponge. J Org Chem.1988;53(25):5941-7.

15. Kalinin VI, Ivanchina NV, Krasokhin VB, Makarieva TN, Stonik VA. Glycosides from Marine Sponges (Porifera, Demospongiae): Structures, Taxonomical Distribution, Biological Activities and Biological Roles. Mar Drugs. 2012;10(8):1671-710.

16. Lee HS, Seo Y, Cho KW, Rho JR, Shin J, Paul VJ. New triterpenoid saponins from the sponge Melophlusisis. J Nat Prod. 2000;63(7):915-9.

17. Jinzhong $X u$, Hasegawa $M$, Harada $K$, Kobayashi $H$, Nagai $H$, Namikoshi $M$. Melophlins PQR, and S: Four new tetramic acid derivatives, from two Palauan marine sponges of the genus Melophlus. Chem Pharm Bull. 2006;54(6):852-4.

18. Herb R, Carroll AR, Yoshida WY, Scheuer PJ, Paul VJ. Polyalkylated cyclopentindoles: Cytotoxic fish antifeedants from a sponge, Axinella sp. Tetrahedron. 1990;46(8):3089-92.

19. Sreelatha S, Jeyachitra A, Padma PR. Antiproliferation and induction of apoptosis by Moringa oleifera leaf extract on human cancer cells. Food and Chemical Toxicology. 2011;49(6):1270-5. 
GRAPHICAL ABSTRACT
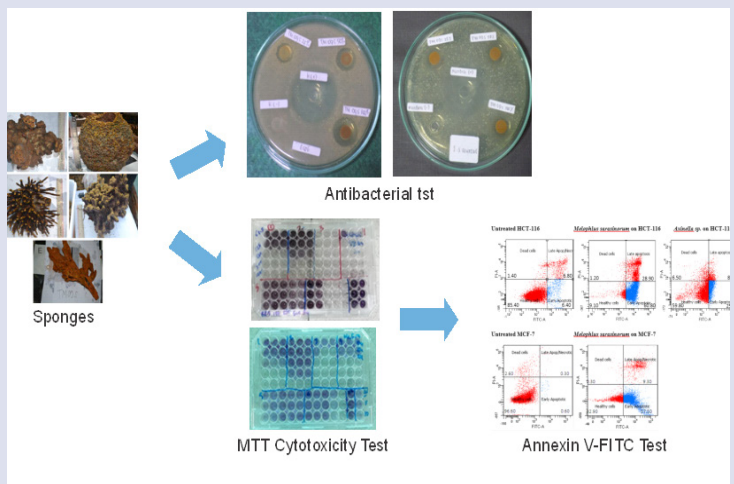

\section{SUMMARY}

- Only extracts of $M$. sarasinorum and Axinella sp exhibited strong inhibition against S.aureus and E.coli

- M. sarasinorum and Axinella sp also showed potent cytotoxicity on HCT-116 with the apoptosis induction mechanism

- Only M. sarasinorum showed moderate growth inhibition on MCF-7 cell lines.

- The cytotoxic mechanism of M. sarasinorum on MCF-7 cell lines was via apoptosis induction.

\section{ABOUT AUTHORS}

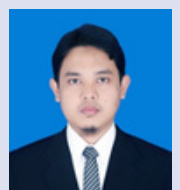

Muhammad Sulaiman Zubair, Associate Professor (Lecturer) at Department of Pharmacy, Faculty of Mathematics and Natural Sciences, Tadulako University, Palu, Indonesia. Research area is natural product and medicinal chemistry. Research topics are herbal drug standardization, secondary metabolite isolation, and marine natural products. He also work on computational research such as virtual screening and docking molecular.

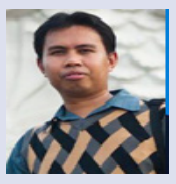

Subehan Lallo, Associate Professor at Faculty of Pharmacy, Hasanuddin University, Makassar, Indonesia. He has research expertise in natural product chemistry.

Masteria Yunovilsa Putra, Researcher at Research Center for Oceanography, Indonesian Institute of Science, Jakarta, Indonesia. He has research expertise in Marine Biotechnology.

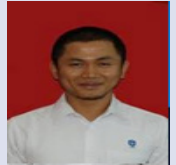

Tri Aryono Hadi, Researcher at Research Center for Oceanography, Indonesian Institute of Science, Jakarta, Indonesia. He has research expertise in marine taxonomy, particularly sponges and soft corals.

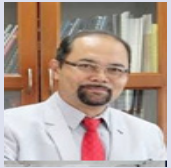

Ibrahim Jantan, Professor of medicinal and natural product chemistry at Faculty of Pharmacy, National University of Malaysia, Malaysia. He has research expertise in pharmacy, medicinal chemistry, organic chemistry, natural products chemistry, biopharmacy, biotechnology and drug discovery. 